\title{
COVID-19, Storms, and Floods: Impacts of Tropical Storm Cristobal in the Western Sector of the Yucatan Peninsula, Mexico
}

\author{
Oscar Frausto-Martínez ${ }^{1, *} \mathbb{*}$, Cesar Daniel Aguilar-Becerra ${ }^{2} \oplus$, Orlando Colín-Olivares ${ }^{3}$, \\ Gabriel Sánchez-Rivera ${ }^{1}{ }^{\mathbb{D}}$, Adel Hafsi ${ }^{1}$, Alex Fernando Contreras-Tax ${ }^{1}$ and \\ Wilberth David Uhu-Yam ${ }^{1}$ \\ 1 Laboratorio de Observación Espacial, Campus Cozumel, Universidad de Quintana Roo, Avenue Andrés \\ Quintana Roo S/N, 77600 Cozumel, Mexico; gsrivera@gmail.com (G.S.-R.); adel.hafsi69@gmail.com (A.H.); \\ 1416958@uqroo.mx (A.F.C.-T.); 1416861@uqroo.mx (W.D.U.-Y.) \\ 2 Regional Development Sciences Center, Autonomous University of Guerrero, Privada de Laurel 13, \\ col. El Roble, 39640 Acapulco, Mexico; caguilar@uagro.mx \\ 3 Instituto Nacional de Estadística y Geografía, Calle Pedro Parga 125, Zona Centro, 20000 Aguascalientes, \\ Mexico; orlando.colin@inegi.org.mx \\ * Correspondence: ofrausto@uqroo.edu.mx
}

Received: 3 September 2020; Accepted: 2 November 2020; Published: 27 November 2020

\begin{abstract}
The presence of extreme hydrometeorological threats has co-occurred with the COVID-19 pandemic, increasing the potential risk of a disaster scenario occurring. The hurricane "Cristobal", which impacted Mexico's tropical regions, presented a high risk of contagion and death caused by the combined effects of violent winds, floods, and evacuations. This work aims to determine whether the presence of concurrent events during the pandemic caused an increase in confirmed positive COVID-19 cases in the Yucatan Peninsula's western sector. To achieve this, a numerical analysis and identification of the tropical storm's extreme characteristics were conducted. Next, a combined analysis of the territorial system subject to flooding and the rainfall level reported during the emergency period was conducted at the municipal level. The third phase consisted of analyzing the confirmed positive cases of COVID-19 at the municipal level on four strategic dates (before, during, observation, and end of the emergency period). Finally, a content analysis of the emergency bulletins, action guides, and disaster declarations was carried out to identify the measures and adaptations implemented during the pandemic. It is recognized that emergency management measures were implemented for municipalities with more than 30 confirmed positive cases of COVID-19 and where the shelter capacity was reduced. Protocols for caring for people were followed, these being one of the leading adaptive methods. From the analyzed data, it can be pointed out that there is no direct evidence for an increase in positive COVID-19 cases in 10 of the municipalities. However, in the case of the municipality of Escarcega, there was a sudden increase in cases from June 8, which continues to grow. Therefore, it is necessary to deepen the study of multiple events to recognize the actions that can prevent catastrophes in these times of crisis.
\end{abstract}

Keywords: multiple risks; resilience; vulnerability; adaptive capacity

\section{Introduction}

In humanity's history, a strong relationship between natural disasters and post-disaster population displacement has been evidenced by the spread of transmissible diseases [1]. Related to this, floods generally cause the failure of public services facilities (such as drinking water, drainage, and health centers), which, in turn, represents a risk factor, since as a result of the collapse of the public healthcare 
system, the incidence of various diseases, such as Salmonella enterica, cholera, hepatitis A and B, and others that are spread by vectors such as malaria and dengue, can increase [1-6]. It should be noted that the symptoms of these diseases are similar to those of COVID-19-fever, headaches, muscle aches, diarrhea, fatigue, and cough $[7,8]$

Lemonick [2] showed that after disasters caused by a natural phenomenon, the risk of disease transmission generally depends on four aspects: (1) the size, health status, and living conditions of the population displaced by the disaster, (2) the presence of overcrowding, (3) inadequate water quality and sanitation, and (4) poor access to health services. In addition to the above, it should also be considered that the prolongation of a disaster can cause the collapse of the economic system itself, an outcome which can also be associated with the spread of disease [3].

The appearance of the new COVID-19 coronavirus has led to considerable concern due to its rapid spread and effects on humans. The Yazdanpanah and Lina [9] virus families were initially transmitted from animals to humans and then transmitted among individuals of a species, mainly by the respiratory route. These viruses' most common effects range from colds to pronounced respiratory syndromes (MERS or SARS). The most frequent symptoms of COVID-19 are fever, dry cough, and fatigue; other symptoms such as curvature, nasal congestion, headache, conjunctivitis, sore throat, diarrhea, loss of taste or smell, skin rash, and discoloration of the fingers or toes have also been documented $[7,8,10]$.

In order to reduce the risk of spreading the virus, numerous measures have been taken to mitigate its effects and sensitize the population about hygiene practices that should be applied in daily life [11]. However, even though a significant effort is being made to contain the pandemic, the adverse natural events mentioned above could cause a disaster and make it even more difficult to control the spread of COVID-19. Some local governments have expressed their concern in this context, since disasters are imminent, and as a result, catastrophic scenarios could arise. From such a situation, complex questions have emerged, for example, how should people evacuate and practice social distancing in a shelter? What about the supplies of food and medical equipment [12]? Are different governments prepared for the intersection of multiple threats and COVID-19?

According to the World Health Organization (WHO) [13], nearly $90 \%$ of disasters in the last 10 years have been linked to flooding phenomena. Moreover, it is estimated that more than 2 million people were affected by floods between 1998 and 2017. In general, floods are characterized by a "level increase of the free surface of the water of the rivers or the sea itself, generating as a consequence of the invasion or penetration of water in places where there is usually not" [14]. Since then, three types of floods have been classified, depending on their nature: flash floods (heavy precipitation), seasonal river floods, and coastal floods (cyclones or storm surges) [13].

To systematize the multi-threat risk management processes, this work aims to present an analysis of the impacts of floods caused by the Cristobal storm on the Mayan communities of the western Yucatan Peninsula in the context of the high point of the COVID-19 pandemic.

\section{Background}

\subsection{The First Scenarios}

The first nations to face the intersection of COVID-19 with a rainy season disaster were Pacific Island countries: the Solomon Islands, Vanuatu, Fiji, and Tonga (see Table 1) [15], when the tropical storm Harold left considerable destruction in its wake at the beginning of April 2020 [16]. Ober and Bakumenko [17] documented some of the obstacles that governments of those nations faced when implementing response plans to face both crises. For example, access and humanitarian aid were reduced by interrupted supply chains, food insecurity, shelters, social distancing, and limited and unequal aid distribution. It should be noted that the remoteness of these nations and the measures taken by their governments have enabled them to avoid facing alarming COVID-19 figures to the present day. Only Fiji has experienced any cases, of which all 18 have already recovered [17]. 
Table 1. Cyclonic events that intersected with the COVID-19 pandemic.

\begin{tabular}{ccc}
\hline Name & Active Date & Affected Country \\
\hline Tropical Cyclone Harold & $1-10$ April & The Solomon Islands, Vanuatu, Fiji, Tonga \\
Typhoon Vongfong & 10-18 May & The Philippines, the Palau Islands \\
Tropical Storm Arthur & 16-20 May & The USA (Florida and South Carolina), Cuba, the Bahamas \\
Tropical Cyclone Amphan & 16-21 May & India (West Bengal, Odisha, Andaman Islands), Bangladesh, Sri Lanka, Bhutan \\
Tropical Storm Bertha & 27 and 28 May & The USA (Florida and South Carolina) \\
Tropical Storm Amanda & 30 and 31 May & El Salvador, Guatemala, Honduras, Belize, Costa Rica, Mexico \\
Tropical Storm Cristobal & $2-10$ June & Guatemala, El Salvador, Belize, Nicaragua, Honduras, Mexico (Yucatan, \\
& & Quintana Roo, Veracruz, Campeche), the USA (Luisiana, Mississippi, Florida) \\
\hline
\end{tabular}

Other countries in the same region of the Pacific were affected by typhoon Vongfong, which was active from 14 to 18 May, affecting Palau, the Philippines, Taiwan, and the Ryukyu Islands. It should be noted that in the Philippines, the authorities sheltered more than 50,000 people [18]. According to the World Health Organization [19], as of 18 May, 11,618 cases of COVID-19 were registered in Mexico, which increased substantially in the following 14 days, reaching 18,638 cases.

Cyclone Amphan, which formed in the North Indian Ocean, displaced thousands of people during the pandemic [20], causing extensive damage in the West Bengal region of East India, where even rescuers tested positive for COVID-19. In addition to India, this cyclone ravaged countries such as Bangladesh, Sri Lanka, and Bhutan [21-23].

On the other hand, the tropical storms Amanda, Arthur, Bertha, and Cristobal developed on the American continent. The storms Amanda and Cristobal were the ones that caused the most damage. The first had stronger impacts on Guatemala, El Salvador, Honduras, Belize, Costa Rica, and southern Mexico [24]. El Salvador reported the most considerable damage. The Cristobal storm, which is the object of the present study's analysis, had its most significant impact in the states of the Yucatan Peninsula, Mexico, particularly in the communities in the western region. Finally, in mid-June, rain caused severe floods in southern China, affecting more than a thousand people in 22 provinces [25]. The above events gave rise to the hypothesis of this study:

Hypothesis 1 (H1). The presence of cyclonic events, such as torrential rains, tropical storms, and hurricanes, increases the number of COVID-19 cases.

Cyclonic events, as shown in Figure 1, leave behind floods whose main identified risks are human and material losses, the growth of viruses and bacteria, contamination of drinking water and food, rupture of networks of water, electricity, and gas, and the loss of crops, heritage, and livestock [14,26]. In the case of a tropical storm, the analysis and forecast of the event's intensity and trajectory allow preparation for a future flood to occur. In Mexico, measures taken before and during a crisis to minimize risks during a tropical storm are identified using the early warning system for tropical cyclones (SIAT) [27].

Based on Figure 1, appropriate measures have to be taken during the intersection of the flood emergency process and COVID-19, which presents challenges for different decision-makers, for example, maintaining social distancing during the evacuation of people from at-risk areas and temporary shelters, where the latter have to operate below their maximum capacity, as well as having sufficient infrastructure and adequate supplies to comply with hygiene measures in order to avoid scenarios that involve an increase in COVID-19 cases due to contagion. 


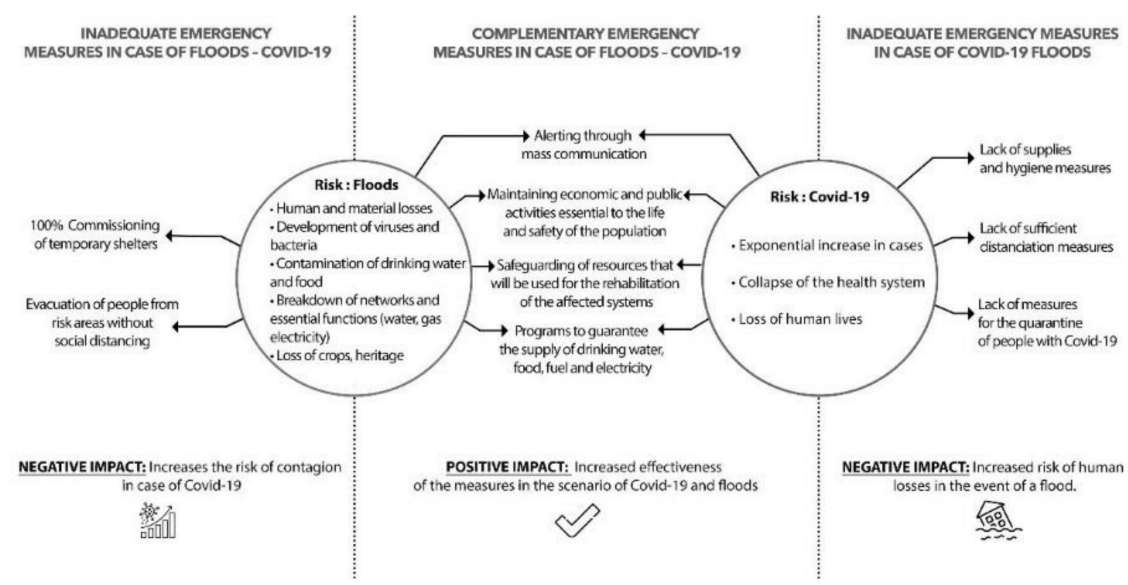

Figure 1. Risks and emergency measures against floods and COVID-19.

\subsection{Flood Resilience Indicators and COVID-19}

Resilience in disaster and risk management favors the use of multi-stakeholder management (public-private-community), and a medium-term strategy in which three phases can be observed has been proposed: preparedness, emergency management, and recovery. According to UNISDR [28], "resilience" is defined as "the capacity of a system, community or society exposed to a threat to resist, absorb, adapt and recover from its effects in a timely and effective manner, including preservation and the restoration of its basic structures and functions." However, it should be mentioned that resilience characteristics vary based on the phase which the system is in. Reghezza-Zitt [29] stated that the goal is to resist, absorb, and maintain the system in the emergency phase. Hence, the measures are reactive (physical, engineering, emergency services, spatial, and social), with the aim being to return to the initial conditions as quickly as possible.

The indicators allow warning signs to be identified to allow informed decision making [30]. In recent years, various frameworks have been proposed to measure resilience to floods in various parts of the world [31-34]. However, no studies have integrated flood resilience indicators and COVID-19 to allow the management and decision making of the parties involved to be evaluated. Table 2 summarizes the indicators that allow emergency management in the presence of floods and COVID-19 and their association with early warnings to be analyzed.

Table 2. Flood emergency management indicators and COVID-19.

\begin{tabular}{|c|c|c|c|}
\hline Indicator & Definition & Importance & Source \\
\hline $\begin{array}{l}\text { Positive cases and } \\
\text { scattering }\end{array}$ & $\begin{array}{l}\text { Number of new local positive } \\
\text { cases of COVID-19 during the } \\
\text { emergency period }\end{array}$ & $\begin{array}{l}\text { In times of crisis, evacuation and accumulation of people in } \\
\text { tightly confined locations for flood-related safety reasons can } \\
\text { increase contagion. }\end{array}$ & [35] \\
\hline $\begin{array}{l}\text { Active hostels and } \\
\text { number of } \\
\text { populations per } \\
\text { hostel }\end{array}$ & $\begin{array}{l}\text { Implementation of hostels } \\
\text { during the contingency period }\end{array}$ & $\begin{array}{l}\text { During a flood, people at risk sites have very few shelter options. } \\
\text { The magnitude of the natural disaster phenomenon and the } \\
\text { limited conditions of withdrawal associated with the study area's } \\
\text { morphological context requires populations to take refuge in } \\
\text { structures capable of resisting the phenomenon. } \\
\text { There is a need for the capacity of structures to accommodate } \\
\text { enough people while allowing them to maintain social distancing } \\
\text { and hygiene measures. }\end{array}$ & {$[36]$} \\
\hline $\begin{array}{l}\text { Activating early } \\
\text { warning system }\end{array}$ & $\begin{array}{l}\text { Number of emergency early } \\
\text { warning releases }\end{array}$ & $\begin{array}{l}\text { This early warning system involves an alert system through the } \\
\text { mass media (newsletters), commissioning of temporary shelters, } \\
\text { evacuation of risk zones, safeguarding of material resources to be } \\
\text { used for the rehabilitation of affected systems, implementation of } \\
\text { programs to ensure sufficient supply of drinking water, food, } \\
\text { fuels, and electricity, and suspension of school activities and } \\
\text { maritime and coastal activities. }\end{array}$ & [27] \\
\hline $\begin{array}{l}\text { Declaration of } \\
\text { emergency and } \\
\text { disaster }\end{array}$ & Emergency declaration & $\begin{array}{l}\text { Emergency declarations allow a crisis to be alleviated and } \\
\text { authorities to be given the resources to meet the health, food, } \\
\text { and shelter needs of the affected population. }\end{array}$ & [37] \\
\hline
\end{tabular}




\subsection{The Hurricane Season: Tropical Storm Cristobal}

The Yucatan Peninsula is subject to the recurrent impact of tropical cyclones, differentiated into diverse impact regions, with a focus on the eastern portion [38,39]. Based on the high probability of impact, the coastal areas of the peninsula are considered as "extreme danger" areas, though no other natural event affects the peninsula as much as tropical hurricanes and their associated events: floods, extreme winds, storm surges, and sudden precipitation [39].

On the other hand, climate change scenarios foresee an increase in the number and intensity of cyclones. This increase is expected to be gradual; therefore, to observe the changes, a long-time series analysis is required [40]. In 2020, the hurricane season in the North Atlantic began with significant activity. Three tropical storms were registered in only the first days (Arthur, Bertha, and Cristobal). The tropical storm Cristobal was generated as a system of continuity to a low-pressure activity that evolved into a tropical storm in the Pacific (Amanda). The storm entered the Yucatan Peninsula from the south, crossing El Salvador and Guatemala in a northern trajectory, with significant rainfall. During its trajectory, which had an irregular nature, punctual torrential precipitation of 60 to $250 \mathrm{~mm}$ was recorded [41,42].

During its passage through the western sector of the Yucatan Peninsula, 35 reports were generated from the hurricane early warning system of the national civil protection system, in which extraordinary rainfall, floods, and a storm surge were detailed, as well as information about territories affected at the municipal level. Specific mention was made about taking necessary measures for those municipalities that, as of 2 June, had reported more than 30 positive cases of COVID-19. Finally, on 15 June, declaration of a natural disaster was made due to the presence of severe rain that occurred from 30 May to 5 June in 11 municipalities of the State of Campeche, located to the west of the Yucatan Peninsula [41].

\section{Materials and Methods}

\subsection{Study Zone}

The Yucatan Peninsula's western sector is administered by the State of Campeche, which includes 11 municipalities. The total population is estimated to be more than one million inhabitants [43] (Figure 2). The State of Campeche is located geographically in the western part of the Yucatan Peninsula, southeast of the national territory, between parallels $17^{\circ} 49^{\prime}$ and $20^{\circ} 51^{\prime}$ North (latitude) and meridians $89^{\circ} 05^{\prime}$ and $92^{\circ} 28^{\prime}$ West (longitude) [44].

\subsection{Data}

- The data regarding the trajectories and physical characteristics of the tropical cyclones that impacted the State of Campeche, Mexico, in the period 1851-2019 were obtained from the International Best Track Archive for Climate Stewardship (IBTrACS), a database administered by the National Oceanic and Atmospheric Administration (NOAA). The information corresponds to version v04r00 and is available on an internet download portal [45].

- The trajectory of the tropical storm Cristobal was obtained from accumulated wind history data from the National Hurricane Center [46].

- The political limits of Mexico and the topographic vector data (contour lines, depressions, land subject to flooding, bodies of water, and rivers) were determined from the Geostatistical Framework distributed by the National Institute of Statistics, Geography, and Informatics, and 81 topographic charts from the State of Campeche at a scale of 1:50,000 were collected [47].

- Data on the emergency declaration of the Government of Campeche and municipalities affected were obtained. The declaration of emergency was published on 16 June 2020 in the Official Gazette of the Federation [37]. Tropical cyclones emergency bulletins were also released by CENAPRED and the early warning system published by the National Meteorological Service, from which data on precipitation, shelters, impacts generated by floods, and municipalities with declarations of emergency were extracted (issued from 30 May to 8 June 2020). 
- The data used as a reference for the COVID-19 data were obtained from the historical open data system of the General Directorate of Epidemiology of the Government of Mexico, which included unique identification data on confirmed cases. In this study, the data included were records from 30 May to 30 June 2020 [48] to align with the impact time of the tropical storm Cristobal from 30 May to 6 June, and the following 15 days of possible contagion from 16 to 22 June, as well as 8 days for prospecting and trend comparison, with the above factors depending on the date of the announcement of the end of the contingency issued by the Coordination of Civil Protection of Mexico [41].

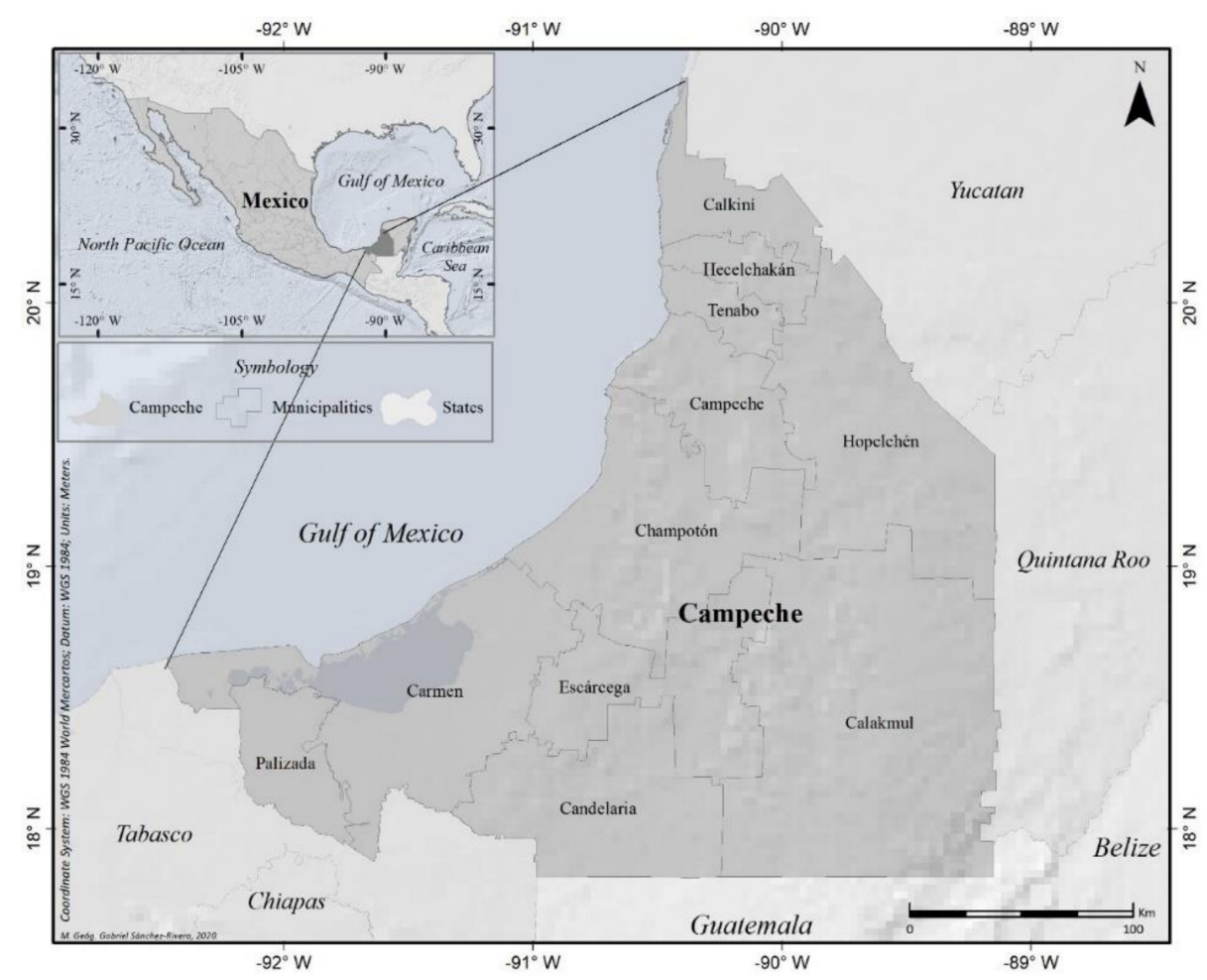

Figure 2. Location of the study area.

\subsection{Methodology}

To conduct the research, the following phases were established:

First, a historical review of hurricanes and storms that have impacted the Yucatan Peninsula's western sector was conducted to determine the incidence and return of events. The observation period was from 1851 to 2019.

Second, different flood zones were determined according to their processes: permanent, ordinary, or extraordinary. To achieve this, an analysis of the negative relief was carried out. This identified the depressions of the terrain through an analysis of the digital elevation model and the areas subject to flooding, bodies of water, and river systems. The flood map is displayed at a resolution scale of $1: 50,000$.

Third, we conducted a review of the declarations of emergency and the report of the declaration of emergency by the Federal Government and the Secretary of Civil Protection of Campeche. For this, the technical report for the emergency declaration of the Government of the State of Campeche was reviewed in order to identify the initiation of the declaration, the magnitude of damage, the number of people attended to in each shelter, and the duration (days) that the emergency lasted. Likewise, the early warning system's notice against tropical cyclones was revised, highlighting the notices for those municipalities that, as of 30 May 2020, had more than 30 confirmed positive cases of COVID-19. 
Fourth, an analysis of the monthly number of confirmed positive cases of COVID-19 at the municipal and state levels was conducted in order to recognize trends throughout the contingency. For this, the data were taken from 30 May (start date of the emergency notices) to 8 June 2020 . For the analysis, four fundamental indicators were considered: (a) positive cases and daily territorial dispersion, (b) active shelters and the number of persons per shelter, (c) activation of the early warning system, and (d) declarations of emergency and disaster. For this, the WHO [10] was taken as a reference. The indicators were disaggregated at the municipal level.

Fifth and finally, as a complement to the contagion data collected during the contingency analysis, the effective reproduction rate (Rt) was calculated for four specific contingency periods. An analysis using the "COVID-19 Estimator" interface was conducted. This is an interface that helps countries estimate the transmission rate of COVID-19 using the number of cases reported on specific dates according to the R package "EpiEstim" [49,50]. From the data of the daily incidence of cases in a region, country, or area, the interface dynamically produces epidemic curves (number of incidents) as a function of time $t$ and the estimate $R$ (reproductive number) as a function of time $t$ with intervals of $95 \%$ confidence. The calculation was performed using weekly sliding windows with a parametric series interval based on a mean of $\mu \mathrm{si}=4.8$ and a standard deviation of $\sigma s i=2.3$.

\section{Results}

Eighty-six identified tropical cyclones have affected the western sector of the Yucatan Peninsula. This includes 44 tropical storms and depressions, 33 category 1 to 3 hurricanes, and 9 category 4-5 hurricanes. Considering the period between 1851 and 2019, the 1930s had the highest cyclonic activity on record, with $15 \%$ of the total number of cyclones occurring during this period. The 1960s recorded the least activity, when only one tropical depression was recorded.

Of all cyclones that have made landfall in the state, five are highlighted due to the intensity of the winds produced and minimal atmospheric impact: Hurricanes Not Named in 1933, Janet in 1955, Edith in 1971, Mitch in 1988, and Dean in 2007. Figure 3 summarizes the tropical cyclones' paths and categories reached while passing through Campeche State.

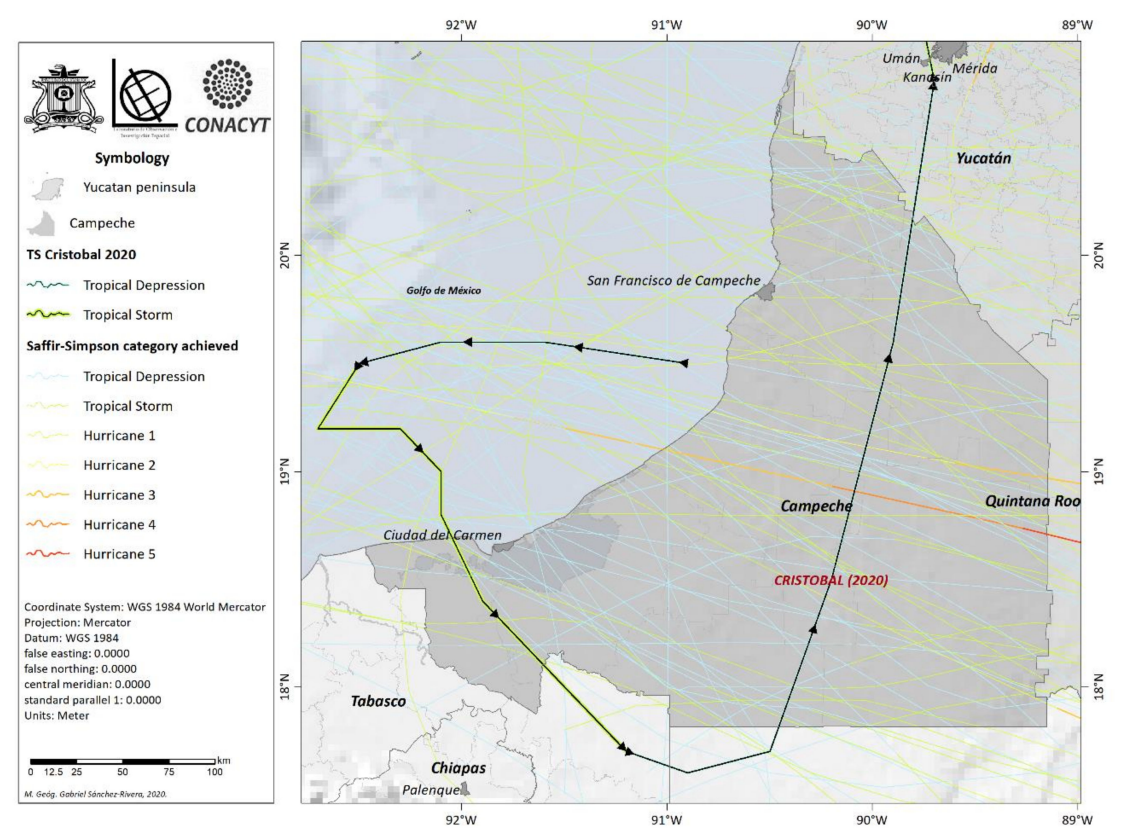

Figure 3. Trajectories of the cyclones characterized as extreme that impacted Campeche State in the period 1851-2019, and the trajectory of the tropical storm Cristobal (2020).

The tropical storm Cristobal caused a nine-day storm with extraordinary torrential rain in the south-southeast of Mexico from 30 May to 7 June 2020. Gusty winds of between 80 and $95 \mathrm{~km} / \mathrm{h}$ were 
predicted with sea-level increases of up to $30 \mathrm{~cm}$ on the coast and waves of 4 to $5 \mathrm{~m}$ in the Campeche surroundings [51]. The precipitation records in June 2020 for the Yucatan Peninsula were $406 \mathrm{~mm}$ in Quintana Roo, $499.1 \mathrm{~mm}$ in Campeche, and $551 \mathrm{~mm}$ in Yucatan State. These values were extraordinary compared with the 2019 records of 68,72 , and $52 \mathrm{~mm}$, respectively [52,53].

One of the notable tropical storm Cristobal features was the volume of precipitation reported for the period from 30 May to 5 June 2020. The accumulated precipitation estimated on each of those days was up to $50 \mathrm{~mm}$ [42]. The rain forecast for the period from 1 to 10 June 2020 was estimated to be $75 \mathrm{~mm}$ and up to $200 \mathrm{~mm}$ [54], with the maximum record of $760 \mathrm{~mm}$ occurring in Xpujil, south of Campeche [55]. Specifically, the precipitation records at the meteorological stations were as follows: Calakmul- $384 \mathrm{~mm}$, Ciudad del Carmen-397 mm, Holpechen-389 mm, and Bolanchen-311 mm [56].

Due to the large amount of rainfall, floods occurred throughout the southwest area of the Yucatan Peninsula and continued for 30 days after the tropical storm started. In Figure 4, the territory's susceptibility to permanent, ordinary, and extraordinary floods is recognized, where the coastline and the coastal plain - the territories subject to flooding — as well as the depressions of karst origin (sinkholes, uvalas, and poljes) were the most affected. The municipalities affected by floods were Calkini, Calakmul, and Hopelchen. In the latter, the towns of Iturbide, Bolonchen, and Ukum reported 80 families affected by floods, while 60 houses were affected in Calkini [37].

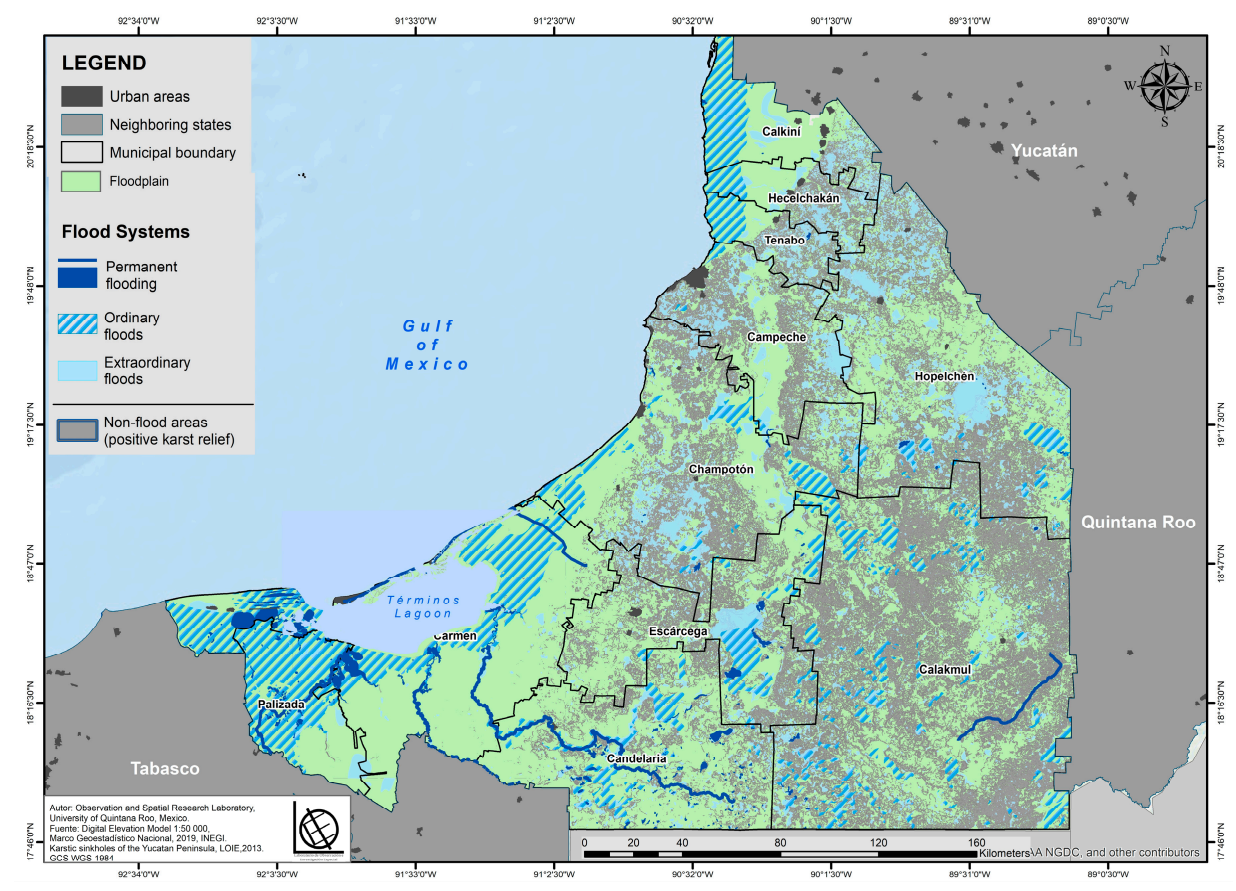

Figure 4. Map showing flood susceptibility of areas in Campeche.

Due to the damages, 13 temporary shelters were opened to serve 719 people, mainly in the municipalities of Hopelchen (three with 123 people affected), Calkini (one with 8 affected), Escarcega (one with 53 affected), Calakmul (four with 320 people), Champoton (one with 7 affected), Campeche (one with 80 affected), and Ciudad del Carmen (one with 130 affected) [56].

One of the central characteristics of the bulletins of the early warning system for tropical cyclones is the signaling of attention to those municipalities with more than 30 positive cases of COVID-19, which must then establish direct protocols for emergency care, establishments of shelters, and specific care during the maximum contingency period (from 30 May to 7 June 2020) [54].

In Mexico, as of 8 March, the Secretary of Health (SS, 2020) had reported 270,003 confirmed cases, 32,796 deaths, 167,795 recovered cases, and 27,891 active cases. The first reported case was on 28 February. For the states of Quintana Roo and Yucatan, the first recorded cases came two weeks later and Campeche had its first case almost a month later [41]. 
At the start of the contingency period in the State of Campeche, 536 positive cases of COVID-19 were registered, and only the municipalities of Carmen and Campeche had more than 30 cases, with 308 and 147 positive cases, respectively. Hence, it was necessary to implement emergency measures associated with COVID-19 in these municipalities to avoid contagion (Figure 5). Figure 6 shows the status of positive cases for four specific dates: start of the emergency (30 May), declaration of disaster (8 June), lifting of the emergency period (21 June), and end of the observation period (8 July), one month after the declaration of disaster.

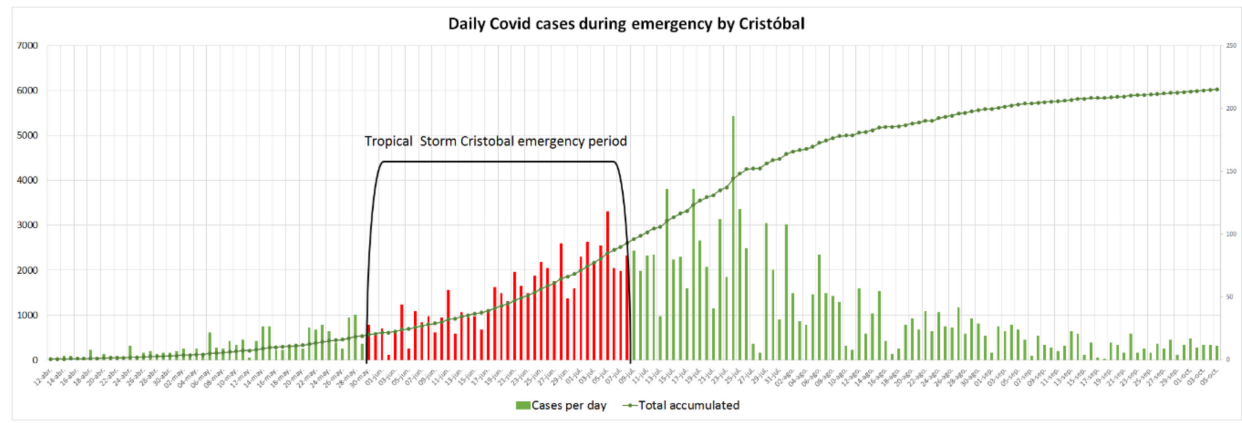

Figure 5. Daily COVID-19 cases during the Cristobal emergency period (GOB, 2020 COVID-19 data [48].
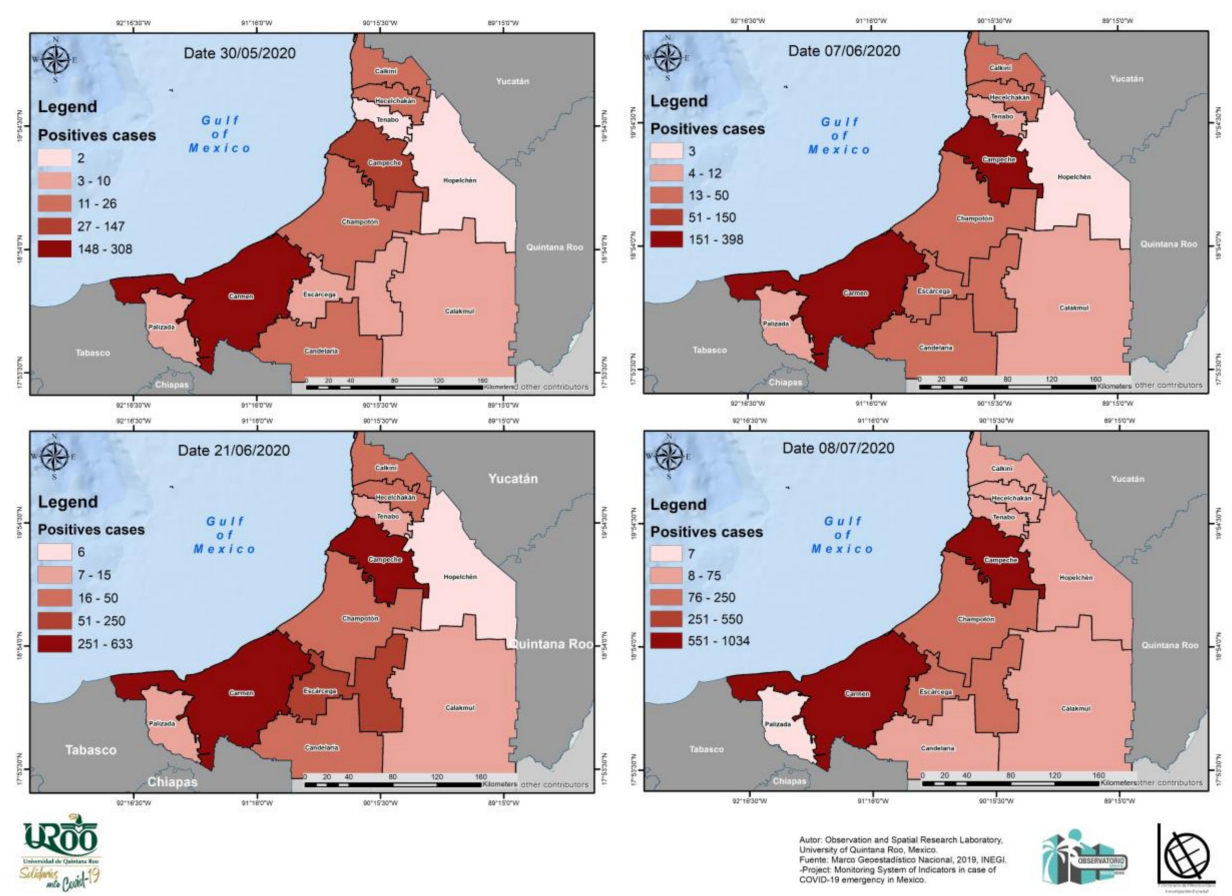

Figure 6. Maps of confirmed COVID-19 cases at the four contingency moments (based on INEGI, 2019 and GOB, 2020 data) $[47,48]$.

Figure 7 shows the confirmed positive cases for the 11 municipalities located in the western sector of the Yucatan Peninsula, in which the progress of the cases during the contingency period is recognized. Although all of the municipalities were included in the declaration of emergency and disaster, shelters were only activated in seven of them. Municipalities in which numbers of positive cases have remained at exceptionally low or stable levels were Palizada, Tenabo, Hecelchenkán, and Candelaria, which all registered between 1 and 16 active cases. 


\begin{tabular}{|c|c|c|c|c|c|c|c|c|c|c|c|c|c|c|c|c|c|c|c|c|c|c|c|c|c|c|c|c|c|c|c|c|c|c|c|c|c|c|c|c|}
\hline Municipalities & $\begin{array}{c}\text { May } \\
30\end{array}$ & $\begin{array}{l}\text { May } \\
31\end{array}$ & & $\begin{array}{l}\text { Jun } \\
02\end{array}$ & $\begin{array}{l}\text { Jun } \\
03\end{array}$ & $\begin{array}{l}\text { Jun } \\
04\end{array}$ & $\begin{array}{l}\text { Jun } \\
05\end{array}$ & & $\begin{array}{c}\text { Jun } \\
07\end{array}$ & \begin{tabular}{|l|} 
Jun \\
08
\end{tabular} & & & $\begin{array}{l}\text { Jun } \\
11\end{array}$ & $\begin{array}{c}\text { Jun } \\
12\end{array}$ & $\begin{array}{c}\text { Jun } \\
13\end{array}$ & $\begin{array}{l}\text { Jun } \\
14\end{array}$ & $\begin{array}{l}\text { Jun } \\
15\end{array}$ & $\begin{array}{l}\text { Jun } \\
16\end{array}$ & $\begin{array}{l}\text { Jun } \\
17\end{array}$ & & $\begin{array}{l}\text { Jun } \\
19\end{array}$ & $\begin{array}{l}\text { Jun } \\
20\end{array}$ & & \begin{tabular}{|l} 
Jun \\
22
\end{tabular} & $\begin{array}{l}\text { Jun } \\
23\end{array}$ & $\begin{array}{l}\text { Jun } \\
24\end{array}$ & $\begin{array}{l}\text { Jun } \\
25\end{array}$ & $\begin{array}{l}\text { Jun } \\
26\end{array}$ & $\begin{array}{l}\text { Jun } \\
27\end{array}$ & $\begin{array}{l}\text { Jun } \\
28\end{array}$ & & $\begin{array}{l}\text { Jun } \\
30\end{array}$ & & & $\begin{array}{l}\text { Jul } \\
03\end{array}$ & $\begin{array}{l}\text { Jul } \\
04\end{array}$ & $\begin{array}{l}\text { Jul } \\
05\end{array}$ & $\begin{array}{l}\text { Jul } \\
06\end{array}$ & $\begin{array}{l}\text { Jul } \\
07\end{array}$ & $\begin{array}{l}\text { Jul } \\
08\end{array}$ \\
\hline Calkiní & 19 & 19 & 19 & 19 & 21 & 22 & 23 & 25 & 25 & 25 & 24 & 26 & 27 & 28 & 28 & 28 & 29 & 29 & 29 & 31 & 32 & 32 & 39 & 39 & 42 & 42 & 45 & 48 & 49 & 51 & 51 & 52 & 54 & 60 & 61 & 62 & 69 & 70 & 70 & 74 \\
\hline Cases & & 0 & 0 & 0 & 2 & 1 & 1 & 2 & 0 & 0 & -1 & 2 & 1 & 1 & 0 & 0 & 1 & 0 & 0 & 2 & 1 & 0 & 7 & 0 & 3 & 0 & 3 & 3 & 1 & 2 & 0 & & 2 & 6 & 1 & 1 & 7 & 1 & 0 & 4 \\
\hline Campec & 147 & 156 & 158 & 159 & 165 & 169 & 176 & 192 & 212 & 2182 & 2222 & 232 & 252 & 259 & 273 & 290 & 300 & 311 & 326 & 345 & 385 & 399 & 419 & 455 & 468 & 505 & 538 & 554 & 593 & 626 & 651 & 685 & 733 & 775 & 812 & 869 & 913 & 956 & 956 & 997 \\
\hline Cases/day & & 9 & 2 & 1 & 6 & 4 & 7 & 16 & 20 & 6 & 4 & 10 & 20 & 7 & 14 & 17 & 10 & 11 & 15 & 15 & 40 & 14 & 20 & 36 & 13 & 37 & 33 & 16 & 39 & 33 & 25 & 34 & 48 & 42 & 37 & 57 & 44 & 43 & 0 & 41 \\
\hline Carmen & 308 & 312 & 335 & 337 & 347 & 3723 & 373 & 391 & 398 & 4234 & $427 \quad 4$ & 445 & 466 & 476 & 499 & 513 & 532 & 543 & 555 & 572 & 572 & 602 & 633 & \begin{tabular}{|l|l|}
647 \\
\end{tabular} & 666 & 679 & 711 & 749 & 754 & 789 & 811 & 823 & 841 & 861 & 875 & 899 & 941 & 959 & 959 & 977 \\
\hline Cases/ & & 4 & 23 & 2 & 10 & 25 & 1 & 18 & 7 & 25 & 4 & 18 & 21 & 10 & 23 & 14 & 19 & 11 & 12 & 17 & $e_{0}$ & 30 & 31 & 14 & 19 & 13 & 32 & 38 & & 35 & 22 & 12 & 18 & 20 & 14 & 24 & 42 & 18 & 0 & 18 \\
\hline Champ & 19 & 24 & 24 & 24 & 24 & 24 & 24 & 24 & 24 & \begin{tabular}{|l|}
27 \\
\end{tabular} & 27 & 27 & 29 & 29 & 30 & 32 & 35 & 36 & 39 & 40 & 42 & 43 & 43 & 45 & 48 & 55 & 55 & 55 & 58 & 62 & 62 & 62 & 62 & 69 & 77 & 81 & 85 & 92 & 92 & 92 \\
\hline Cases/ & & 5 & 0 & 0 & 0 & 0 & 0 & 0 & 0 & 3 & 0 & 0 & 2 & 0 & 1 & 2 & 3 & 1 & 3 & 1 & 2 & 1 & 0 & & 3 & & 0 & 0 & 3 & & 0 & 0 & & 7 & & 4 & 4 & 7 & 0 & 0 \\
\hline Hecelchaka & 18 & 18 & 18 & 18 & 21 & 21 & 21 & 21 & 21 & 22 & 21 & 22 & 22 & 22 & 22 & 22 & 22 & 22 & 23 & 25 & 27 & 28 & 30 & 30 & 30 & 32 & 33 & 34 & 38 & 42 & 43 & 43 & 50 & 51 & 56 & 56 & 65 & 65 & 65 & 66 \\
\hline Cases/day & & 0 & 0 & 0 & 3 & 0 & 0 & 0 & 0 & 1 & -1 & 1 & 0 & 0 & 0 & 0 & 0 & 0 & 1 & 2 & 2 & 1 & 2 & 0 & 0 & 2 & 1 & & 4 & 4 & 1 & 0 & 7 & 1 & 5 & 0 & 9 & 0 & 0 & 1 \\
\hline Hopelchén & 2 & 2 & 2 & 2 & 2 & 3 & 3 & 3 & 3 & 3 & 3 & 3 & 3 & 3 & 3 & 4 & 4 & 4 & 4 & 5 & 6 & 6 & 6 & 9 & 13 & 13 & 13 & 18 & 18 & 19 & 19 & 20 & 20 & 22 & 23 & 23 & 23 & 23 & 23 & 23 \\
\hline Cases/day & & 0 & 0 & 0 & 0 & 1 & 0 & 0 & 0 & 0 & 0 & 0 & 0 & 0 & 0 & 1 & 0 & 0 & 0 & 1 & 1 & 0 & 0 & & 4 & U & 0 & & & 1 & 0 & & U & 2 & 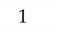 & 0 & 0 & 0 & 0 & 0 \\
\hline Paliza & 7 & 7 & 7 & 7 & 7 & 7 & 7 & 7 & 7 & 7 & 7 & 7 & 7 & 7 & 7 & 7 & & & ren & & & & & & & & & & & & & & & & & & & 7 & 7 & 7 \\
\hline Cases/day & & 0 & 0 & 0 & 0 & 0 & 0 & 0 & 0 & 0 & 0 & 0 & 0 & 0 & 0 & 0 & 0 & 0 & 0 & 0 & 0 & 0 & 0 & 0 & 0 & 0 & 0 & 0 & 0 & 0 & 0 & 0 & 0 & 0 & 0 & 0 & 0 & 0 & 0 & 0 \\
\hline Tenabo & 2 & 2 & 2 & 2 & 4 & 5 & 5 & 6 & 8 & 8 & 8 & 8 & 8 & 8 & 8 & 8 & 10 & 10 & 11 & 11 & 13 & 14 & 15 & 15 & 15 & 19 & 20 & 21 & 21 & 21 & 22 & 22 & 24 & 27 & 27 & 28 & 36 & 36 & 36 & 36 \\
\hline Cases/day & & 0 & 0 & 0 & 2 & 1 & 0 & 1 & 2 & 0 & 0 & 0 & 0 & 0 & 0 & 0 & 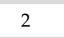 & 0 & 1 & 0 & 2 & 1 & 1 & 0 & 0 & 4 & 1 & 1 & 0 & 0 & 1 & 0 & 2 & 3 & 0 & 1 & 8 & 0 & 0 & 0 \\
\hline Escarcega & 10 & 11 & 11 & 12 & 12 & 24 & 24 & 25 & 26 & 26 & 42 & 45 & 57 & 58 & 58 & 58 & 58 & 59 & 66 & 81 & 85 & 85 & 94 & 95 & 105 & 109 & 113 & 121 & 132 & 141 & 142 & 150 & 154 & 166 & 178 & 182 & 185 & 188 & 188 & 192 \\
\hline Cases/day & & 1 & 0 & 1 & 0 & 12 & 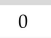 & 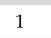 & 1 & 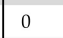 & 16 & 3 & 12 & 1 & 0 & 0 & 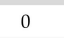 & 1 & 7 & 15 & 4 & 0 & 9 & 1 & 10 & 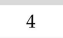 & 4 & 8 & 11 & 9 & 1 & 8 & 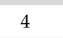 & 12 & 12 & 4 & 3 & 3 & 0 & 4 \\
\hline Calakmul & 6 & 6 & 6 & 6 & 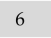 & 6 & 6 & 7 & 7 & 7 & 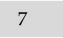 & 7 & 7 & 7 & 7 & 7 & 7 & 7 & 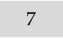 & 7 & & 7 & r & 7 & & & . & 10 & 10 & 14 & 14 & 14 & 14 & 15 & 15 & 15 & 15 & 16 & 16 & 18 \\
\hline Cases/day & & 0 & 0 & 0 & 0 & 0 & 0 & 1 & 0 & 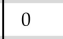 & 0 & 0 & 0 & 0 & 0 & 0 & 0 & 0 & c & 0 & 0 & 0 & 0 & 0 & 1 & 0 & 1 & 1 & 0 & 4 & 0 & 0 & 0 & 1 & 0 & 0 & 0 & 1 & 0 & 2 \\
\hline Candelaria & 26 & 26 & 26 & 26 & 26 & 26 & 26 & 26 & 26 & 26 & 26 & 26 & 26 & 28 & 28 & 28 & 28 & 28 & 29 & 30 & 31 & 31 & 31 & 34 & 34 & 34 & 37 & 37 & 37 & 38 & 38 & 38 & 39 & 39 & 39 & 39 & 40 & 40 & 40 & 41 \\
\hline Cases/day & & 0 & 0 & 0 & 0 & 0 & 0 & 0 & 0 & 0 & 0 & 0 & 0 & 2 & 0 & 0 & 0 & 0 & 1 & 1 & 1 & 0 & 0 & 3 & 0 & 0 & 3 & 0 & 0 & 1 & 0 & 0 & 1 & 0 & 0 & 0 & 1 & 0 & 0 & 1 \\
\hline $\begin{array}{c}\text { Campeche } \\
\text { State }\end{array}$ & 563 & 583 & 608 & 612 & 635 & 679 & 688 & 727 & 757 & 792 & 81 & 848 & 90 & 92 & 96 & 997 & 1032 & 1056 & 1096 & 1154 & 1207 & 1254 & 132 & 1383 & 143 & 150 & 158 & 165 & 171 & 181 & 185 & 191 & 191 & & 19 & & & & & \\
\hline ases/day & & 20 & 25 & 4 & 23 & 44 & 9 & 39 & 30 & 35 & 22 & 34 & 56 & 21 & 38 & 34 & 35 & 24 & 40 & 58 & 53 & 47 & 70 & 59 & 53 & 67 & 78 & 73 & 63 & 93 & 49 & 57 & 0 & 82 & 94 & 78 & 91 & 118 & 73 & 71 \\
\hline eriod & & & & & & & & & 194 & & & & & & & & & & & & & & 532 & & & & & & & & & & & & & & & & & 114 \\
\hline
\end{tabular}

Figure 7. COVID-19-confirmed cases in Campeche-accumulated and per day at the municipal and state levels. 
The municipalities of Campeche and Carmen presented conditions to activate prevention protocols in emergency shelters, given that they had more than 30 positive cases (147 and 308, respectively). Figure 8 shows the frequency of cases during the tropical storm Cristobal, where a tendency for cases to increase was recognized. In Escarcega and Calakmul, the increase was sudden as of 7 July, going from 10 positive cases at the start of the emergency to 26 at the declaration of disaster, 94 on 21 July, and then 192 at the lifting of the declaration, with an average daily rate of 4.55 positive cases per day. The highest number of confirmed cases was reached on 9 June for the Escarcega municipality, with 16 cases.

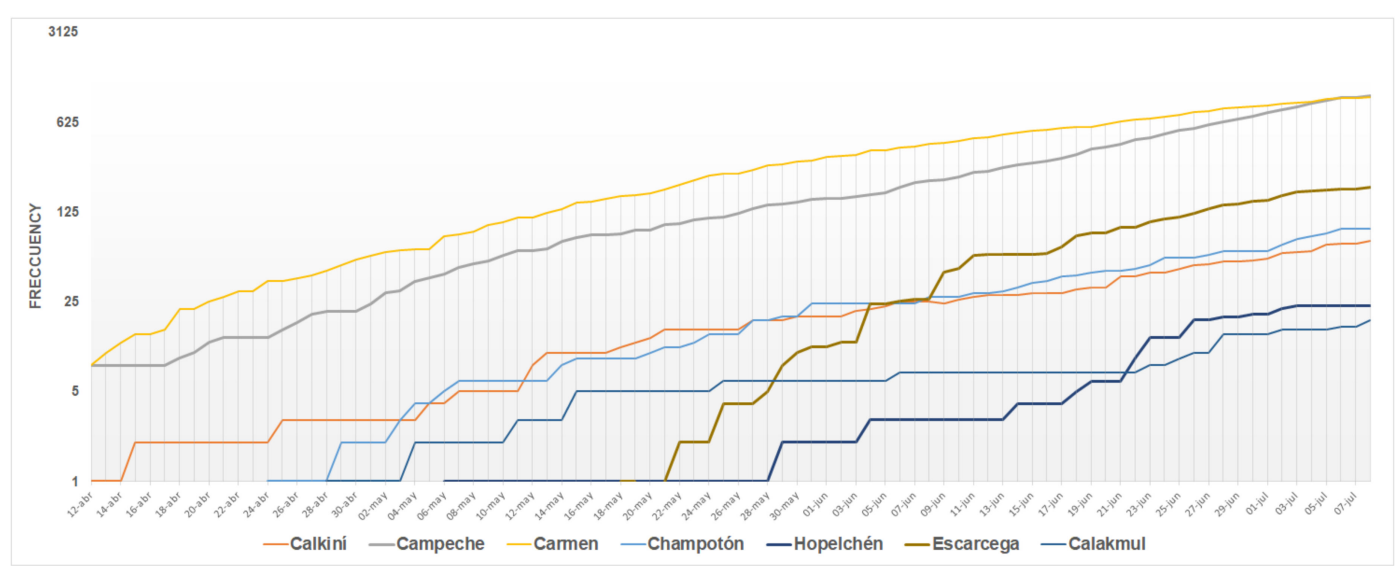

Figure 8. Frequency of positive COVID-19 cases in the western municipalities of the Yucatan Peninsula (data source: General Directorate of Epidemiology of the Government of Mexico, GOB, 2020).

Although the municipalities of Carmen and Campeche reported average daily rates of 16.7 and 21.3 positive cases for these 40 days, their trends did not differ from those for the days before the contingency. Meanwhile, the municipalities of Calkiní and Champoton presented rates of 1.2 and 1.38 cases per day from 30 May to 8 July. There was trend for an increase in cases per day during the observation period, which was continuous; however, it was only possible to affirm a trend of significant increase during the contingency period in the municipality of Escarcega (Figure 9).

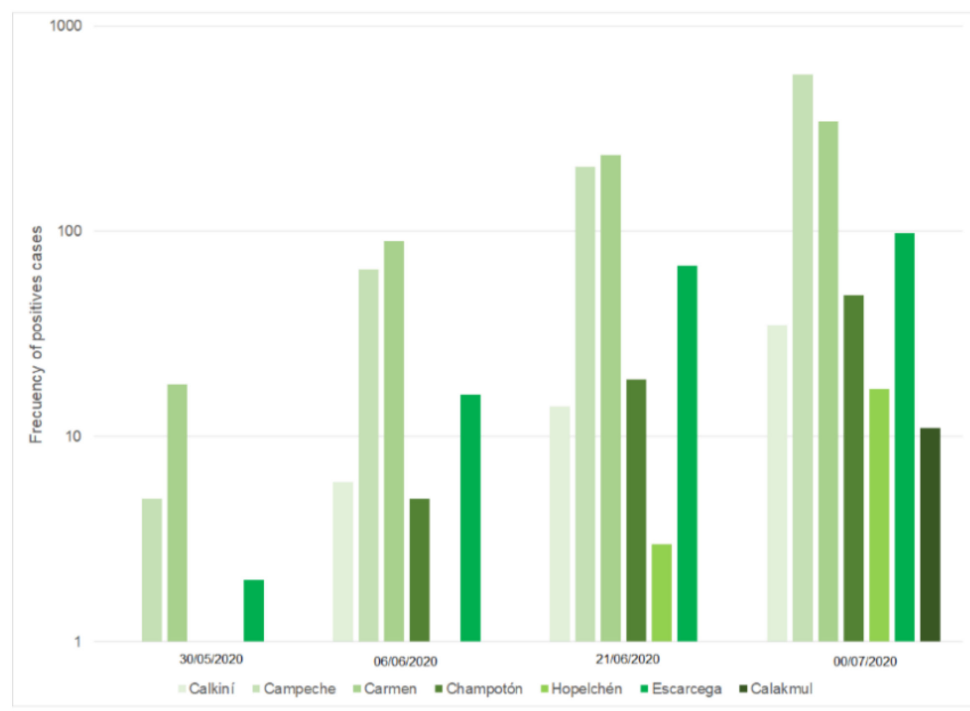

Figure 9. Distribution of cases by municipality at four moments during the contingency period [48].

Additionally, a general Rt analysis of the daily incidence of positive COVID-19 cases in the State of Campeche during the emergency periods was carried out (Figure 10). The estimated Rt value within 
the general pandemic period (12 April 2020-5 October 2020) was 1.05. On the other hand, the estimated Rt value for the emergency initiation period (30 May 2020-7 June 2020) was 1.05, the Rt value for the disaster declaration period (8 June 2020-20 June 2020) was 1.37, and the Rt value for the emergency lifting period (21 June 2020-8 July 2020) was 1.18 (Figure 11). An Rt value of 1 means that the pandemic is in a stable state; for each infected person, another is infected, and when the first recovers or dies, the second replaces them. Thus, at an Rt value of less than 1 , the epidemic disappears, and at an Rt value of greater than 1 , the epidemic will grow, quite possibly exponentially. It is recognized that during the emergency period from 8 to 20 June 2020, the maximum number of infections was reported.

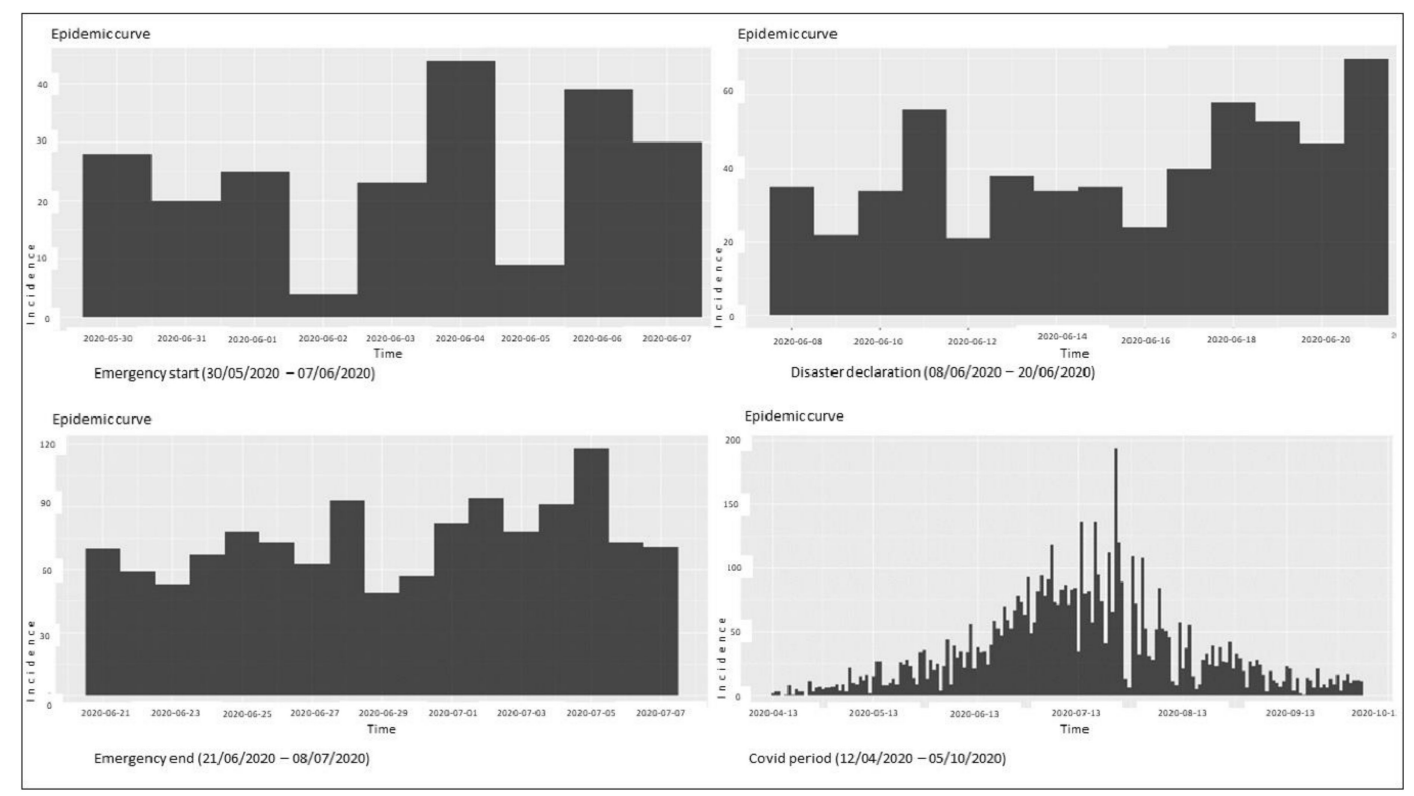

Figure 10. Positive COVID-19 cases for Campeche and their frequency during the three analysis periods and the distribution of cases from 12 April to 5 October 2020 [48].

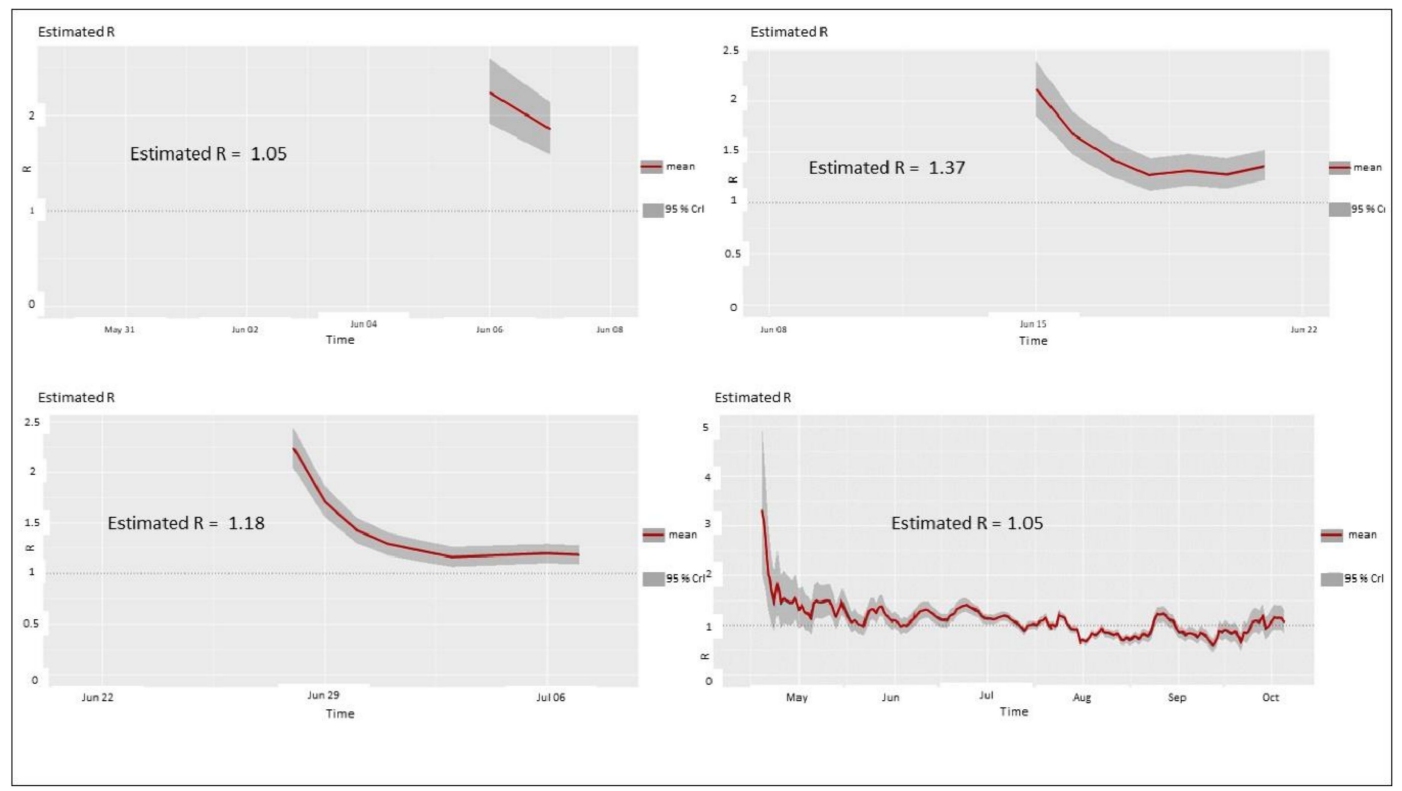

Figure 11. Estimated effective reproduction rate (Rt) values for Campeche and their frequency during the three analysis periods and the distribution of cases from 12 April to 5 October 2020 [48]. 


\section{Discussion}

During the current pandemic, emergency management has been put in place following the occurrence of multiple high-risk events, such as earthquakes, floods, extreme droughts, or temporary illness. Quigley et al. [57] stated that management of such scenarios requires high government commitment, clear hierarchical decisions, protocol systems, operations, and transparency in operation and response. Its disarticulation would be reflected in a cascade effect that would cause a disaster [58].

Although there are action protocols for managing emergencies in Mexico, they are presented in a disarticulated manner. An example is the "Guide for the prevention, preparation, and management of emergencies in the context of COVID-19" [52], which establishes the adaptations to the reference protocols for actions in case of emergencies.

The hierarchy of action for an emergency is multilevel, depending on the type of threat, in this case, a multinational tropical storm (Christopher), and local impacts (extreme rainfall, storm surge, floods) within the context of high socioeconomic vulnerability, as well as links to the COVID-19 emergency (social distancing, reduction of exposure, constant handwashing, suspension of economic and school activities, and closure of public spaces and beaches).

As a significant element of the prevention phase, the early warning system for tropical cyclones in Mexico was established [27], in which the trajectory and intensity of the cyclones are reported through bulletins, with special attention paid to sites that exceed 30 confirmed positive cases, where actions to adapt shelters must be implemented (reduction in the number of people, implementation of cleaning and disinfection protocols, community health supervision brigades, and provision of hygiene supplies, water, and electricity, as well as nurses and alert doctors).

Concerning the potential increase in cases in multi-threat contingencies, it has been identified that, although the capacity was reduced due to the direct impact of events (storms, earthquakes, floods), there were no sudden increases in cases after the contingency period [57] in 10 of the 11 municipalities analyzed. However, in the municipality of Escarcega, the maximum number of positive cases reported occurred on 8 June, nine days after the start of the contingency period and one day after the publication of the declaration of disaster. On 17 June, 15 new cases were reported, totaling 66 people with a positive diagnosis. For 2 and 3 July, 24 new cases were added (12 for each day). Lastly, an increase of 177 cases from 10 on 30 May to 187 on 7 July 2020 was recorded.

The actions that served as a basis to avoid sudden increases in cases were associated with the implementation of action protocols in municipalities with more than 30 confirmed positive cases, a reduction in shelter capacity, hygiene actions for people affected, and activation of community health brigades during the declaration of the emergency. Thus, there was an emergency declaration for the entire State of Campeche, which involved the 11 municipalities, highlighting the characteristics of the threat (precipitation and floods), localities, and affected populations, activation of shelters, and identification of damage to housing structures, public infrastructure, and agricultural and forestry systems. No loss of human life was reported.

Finally, the system of fundamental indicators of resilience to contingencies shows that, under a monitoring scheme, it is possible to articulate the essential functions required to manage situations where threats of various types come together. This is done by considering the control of base data and its daily monitoring, articulating efforts (under a national emergency, the national army applies the DNIII Plan) and action protocols (the development and adaptation of guides and manuals for emergency response centers), and recognizing changes between phases of emergencies (alert, emergency, declaration of disaster, and recovery).

\section{Conclusions}

The conjunction of natural disaster situations during the COVID-19 contingency period is one of the primary contemporary concerns when managing emergencies at different scales of action. At the international and national levels, the implementation of action protocols is oriented toward 
the recognition of multiple threats and the adaptation of protocols in the context of civil protection agencies and early warning systems.

The presence of threats with annual or seasonal recurrence, such as fires, extreme rains, tropical cyclones, and floods, as well as pneumonia, allergies, and dengue, among other conditions, has led to the preparation and adaptation of action protocols. In the case of Mexico, risk prevention action guidelines have been generated for the COVID-19 contingency as an adaptation response to six months of contingency.

In the western sector of the Yucatan Peninsula, a direct relationship was not identified between the sudden increase in infections and confirmed positive cases in the 11 municipalities. An increase in cases was recognized, but with a trend similar to that of the whole country. In the onset period of the pandemic, the Rt was below 1.37 .

Only one municipality had a sudden increase in cases during the contingency and disaster period, from 10 to 44 cases in just 7 days and a doubling of cases in 14 days, reaching 194 cases by the end of the contingency step but with a lower contagion rate. To verify this hypothesis, we must investigate the municipal epidemiological bulletins of weeks 25-28 of 2020 and identify the presence of other diseases to carry out a specific study of confirmed cases and distinguish the localities affected and forms of infection. These data could be used to improve local emergency response protocols.

Author Contributions: Conceptualization, O.F.-M.; Methodology, O.-F.M.; C.D.A.-B. and O.C.-O.; Software, O.C.-O.; G.S.-R.; Validation, O.F.-M., O.C.-O. and C.D.A.-B.; Formal Analysis, O.C.-O.; O.F.-M. and A.H.; Investigation, O.F.-M.; O.C.-O. and C.D.A.-B.; Resources, O.F.-M.; Data Curation, G.S.-R.; A.F.C.-T.; W.D.U.-Y.; O.C.-O.; Writing - Review \& Editing, O.F.-M.; C.D.A.-B.; O.C.-O.; A.H.; and G.S.-R.; Visualization, G.S.-R.; O.C.-O.; A.H. and O.F.-M.; Supervision, O.F.-M.; Funding Acquisition, O.F.-M. All authors have read and agreed to the published version of the manuscript.

Funding: This research received no external funding.

Acknowledgments: We thank the University of Quintana Roo for its support in developing the project "COVID-19 emergency management indicators in Quintana Roo".

Conflicts of Interest: The authors declare no conflict of interest.

\section{References}

1. Watson, J.T.; Gayer, M.; Connolly, M.A. Epidemics after natural disasters. Emerg. Infect. Dis. 2007, $13,1$. [CrossRef] [PubMed]

2. Lemonick, D.M. Epidemics after natural disasters. Am. J. Clin. Med. 2011, 8, 144-152.

3. Kouadio, I.K.; Aljunid, S.; Kamigaki, T.; Hammad, K.; Oshitani, H. Infectious diseases following natural disasters: Prevention and control measures. Expert Rev. Anti-Infect. Ther. 2012, 10, 95-104. [CrossRef] [PubMed]

4. Bhowmick, G.D.; Dhar, D.; Nath, D.; Ghangrekar, M.M.; Banerjee, R.; Das, S.; Chatterjee, J. Coronavirus disease 2019 (COVID-19) outbreak: Some serious consequences with urban and rural water cycle. NPJ Clean Water 2020, 3, 1-8. [CrossRef]

5. Ebrahim, S.H.; Rahman, N.M.; Imtiaz, R.; Gozzer, E.; Alqahtani, S.A.; Ahmed, Y.; Memish, Z.A. Forward planning for disaster-related mass gatherings amid COVID-19. Lancet Planet. Health 2020, 4, e379-e380. [CrossRef]

6. Ridwan, R. COVID-19 and dengue: A deadly duo. Trop. Dr. 2020, 50, 270-272. [CrossRef]

7. Martins-Filho, P.R.; Tavares, C.S.S.; Santos, V.S. Factors associated with mortality in patients with COVID-19. A quantitative evidence synthesis of clinical and laboratory data. Eur. J. Intern. Med. 2020, 76, 97-99. [CrossRef]

8. Qiu, J. Covert coronavirus infections could be seeding new outbreaks. Nature 2020. [CrossRef]

9. Yazdanpanah, Y.; Lina, B. Coronavirus et COVID-19 Sous titre Du Simple Rhume au Syndrome Respiratoire Aigu Sévère. Available online: https://www.inserm.fr/information-en-sante/dossiersinformation/coronavirus-sars-cov-et-mers-cov (accessed on 8 June 2020). 
10. World Health Organization. Q\&A on Coronaviruses (COVID-19). Available online: https://www.who.int/ emergencies/diseases/novel-coronavirus-2019/question-and-answers-hub/q-a-detail/q-a-coronaviruses (accessed on 8 June 2020).

11. Sohrabi, C.; Alsafi, Z.; O’Neill, N.; Khan, M.; Kerwan, A.; Al-Jabir, A.; Iosifidis, C.; Agha, R. World Health Organization declares global emergency: A review of the 2019 novel coronavirus (COVID-19). Int. J. Surg. 2020, 76, 71-76. [CrossRef]

12. Miller, K.; McGrath, G. Hurricanes in a Pandemic 'Absolutely that's Our Nightmare Scenario'. Available online: https://www.usatoday.com/story/news/2020/04/02/hurricane-season-in-june-duringcoronavirus-pandemic/5111024002/ (accessed on 11 June 2020).

13. World Health Organization. Floods. Available online: https://www.who.int/health-topics/floods?fbclid= IwAR1xDiSs8W1RLVyrZzK68m-3lyEQkmDV-_RIz7a0vva4sqOaVBFFWvR4vZ0\#tab=tab_1 (accessed on 8 June 2020).

14. CENAPRED. Inundaciones; Centro Nacional de Prevención de Desastres: Mexico, NM, USA, 2009.

15. Phillips, C.A.; Caldas, A.; Cleetus, R.; Dahl, K.A.; Declet-Barreto, J.; Licker, R.; Merner, L.D.; Ortiz-Partida, J.P.; Phelan, A.L.; Spanger-Siegfried, E. Compound climate risks in the COVID-19 pandemic. Nat. Clim. Chang. 2020, 1-3. [CrossRef]

16. FAO. The Pacific Islands: Tropical Cyclone Harold—Situation Report May 2020. Available online: http: //www.fao.org/emergencies/resources/documents/resources-detail/en/c/1274007/ (accessed on 9 June 2020).

17. Ober, K.; Bakumenko, S. Issue Brief: A New Vulnerability: COVID-19 and Tropical Cyclone Harold Create the Perfect Storm in the Pacific. Available online: https:/www.refugeesinternational.org/reports/2020/6/1/anew-vulnerability-COVID-19-and-tropical-cyclone-harold-create-the-perfect-storm-in-the-pacific (accessed on 6 June 2020).

18. Gutierrez, J. Severe Tropical Storm Vongfong Takes Aim at Philippine Heartland. Available online: https://www.nytimes.com/2020/05/15/world/asia/typhoon-vongfong-philippines-luzon.html (accessed on 12 June 2020).

19. World Health Organization. COVID-19 Dasboard for the Western Pacific Region. Available online: https://worldhealthorg.shinyapps.io/wprocovid19/ (accessed on 6 June 2020).

20. OCHA. Bangladesh: Cyclone Amphan Affects 10 Million People Amid COVID-19. Available online: https://www.unocha.org/story/bangladesh-cyclone-amphan-affects-10-million-people-amid-COVID-19 (accessed on 11 June 2020).

21. Dema, C. Incessant Rainfall Cause Damage in Tsirang. Available online: https://kuenselonline.com/incessantrainfall-cause-damage-in-tsirang/ (accessed on 10 June 2020).

22. Korosec, M. Tropical Cyclone Amphan (Bay of Bengal) Could Become One of the Most Intense Category 5 on Record in the North Indian Ocean-Major Indian City Kolkata in Its Direct Path. Available online: https://www.severe-weather.eu/tropical-weather/india-cyclone-amphan-bengal-mk/amp/ (accessed on 10 June 2020).

23. Nagchoudhary, S.; Ruma, P. Cyclone Kills 14 in India, Bangladesh Leaving Trail of Destruction. Available online: https://www.reuters.com/article/us-asia-storm-india/cyclone-kills-14-in-india-bangladeshleaving-trail-of-destruction-idUSKBN22W0MT (accessed on 10 June 2020).

24. NOAA. Tropical Storm Amanda. Available online: https://www.nhc.noaa.gov/archive/2020/ep02/ep022020. public_a.003.shtml? (accessed on 6 June 2020).

25. Fedschun, T. China Floods Kill 5 More, as Rainstorms Impact Some 700,000 Residents. Available online: https: //www.foxnews.com/world/china-flood-rainstorm-guizhou-hunan-province-weather-flooding (accessed on 15 June 2020).

26. IFRC. Hydrological Hazards: General Floods and Flash Floods. Available online: https: //www.ifrc.org/en/what-we-do/disaster-management/about-disasters/definition-of-hazard/floods/ ?fbclid=IwAR0Kid1gMRtM1DScZfEjMNLrGG9SRqFoOANddcnT-aogNTHsUmM_EeVS4rY (accessed on 8 June 2020).

27. SEGOB. Manual del Sistema de Alerta Temprana para Ciclones Tropicales (SIAT-CT). Available online: https://www.gob.mx/segob/documentos/manual-del-sistema-de-alerta-temprana-para-ciclonestropicales-siat-ct (accessed on 17 May 2020).

28. UNISDR. Sendai Framework for Disaster Risk Reduction 2015-2030. In Proceedings of the 3rd United Nations World Conference on DRR, Sendai, Japan, 14-18 March 2015; pp. 14-18. 
29. Reghezza-Zitt, M. Utiliser la polysémie de la résilience pour comprendre les différentes approches du risque et leur possible articulation. EchoGéo 2013. [CrossRef]

30. Frausto-Martínez, O.; Colín-Olivares, O. Indicadores de Sustentabilidad de la Política de Mares y Costas-México. Rev. Costas 2020, 1, 41-58. [CrossRef]

31. Abenayake, C.C.; Mikami, Y.; Matsuda, Y.; Jayasinghe, A. Ecosystem services-based composite indicator for assessing community resilience to floods. Environ. Dev. 2018, 27, 34-46. [CrossRef]

32. Kotzee, I.; Reyers, B. Piloting a social-ecological index for measuring flood resilience: A composite index approach. Ecol. Indic. 2016, 60, 45-53. [CrossRef]

33. Qasim, S.; Qasim, M.; Shrestha, R.P.; Khan, A.N.; Tun, K.; Ashraf, M. Community resilience to flood hazards in Khyber Pukhthunkhwa province of Pakistan. Int. J. Dis. Risk Reduct. 2016, 18, 100-106. [CrossRef]

34. Xu, W.; Zhong, M.; Hong, Y.; Lin, K. Enhancing community resilience to urban floods with a network structuring model. Saf. Sci. 2020, 127, 104699. [CrossRef]

35. Kvalsvig, A.; Barnard, L.T.; Gray, L.; Wilson, N.; Baker, M. Supporting the COVID-19 Pandemic Response: Surveillance and Outbreak Analytics; University of Otago Wellington: Wellington, New Zealand, 2020; pp. 1-33.

36. Figueiredo, L.; Honiden, T.; Schumann, A. Indicators for Resilient Cities. OECD Reg. Dev. Work. Pap. 2018. [CrossRef]

37. DOF. Declaratoria de Emergencia por la Presencia de Lluvia Severa Ocurrida del 30 de Mayo al 5 de Junio de 2020 en 11 Municipios del Estado de Campeche. Available online: http://dof.gob.mx/nota_detalle.php? codigo $=5595026 \&$ fecha $=16 / 06 / 2020$ (accessed on 16 June 2020).

38. Aponte, G.P.; de Almeida, P.S.A.; Casarín, R.S.; Bautista, E.; Vanegas, G.P.; Val, R. Diagnóstico de Riesgo por Inundaciones para la Ciudad de Campeche; CENTRO EDOMEX-UAC: Mexico, NM, USA, 2005.

39. Ihl, T.; Frausto, O. El cambio Climático y los Huracanes en la Península de Yucatán. In Monitoreo de Riesgo y Desastre Asociados a Fenómenos Hidrometeorológicos y Cambio Climático; Universidad de Quintana: Roo Chetumal, Mexico, 2014; pp. 42-49.

40. Lazos-Chavero, E.; Mwampamba, T.H.; García-Frapolli, E. Uncovering links between livelihoods, land-use practices, vulnerability and forests after hurricane Jova in Jalisco, Mexico. For. Ecol. Manag. 2018, 426, 27-38. [CrossRef]

41. SEGOB. Boletín del Sistema de Alerta Temprana para Ciclones Tropicales SIAT-CT: TT Cristobal AT. Available online: https://www.gob.mx/cms/uploads/attachment/file/555732/TT_CRISTOBAL_19_04062020. pdf (accessed on 8 June 2020).

42. NASA-EO. Cristobal Drenches Central America. Available online: Earthobservatory.nasa.gov/images/ 146817/cristobal-drenches-central-america (accessed on 11 June 2020).

43. COESPO. Indicadores Sociodemográficos del estad0 de Campeche 2016-2050. Available online: http://www.coespo.campeche.gob.mx/index.php/13-coespo/199-informacion-estadistica?fbclid= IwAR3NHwhkfai3jnAxWA4GuNeAQf22BQ9N7FwGBVxBCvkJaJaWgd4v8Glc1r8 (accessed on 8 June 2020).

44. Rivera-Arriaga, E.; López Chan, O.; León Olea, R.; Paredes, J.; Arjona García, M.; Espejel, I.; Zetina, R.; Villalobos Zapata, G. El Ordenamiento de la Zona Costera de Campeche; Educosta: México, NM, USA, 2019.

45. NOAA. International Best Track Archive for Climate Stewardship (IBTrACS). Available online: https: //www.ncdc.noaa.gov/ibtracs/index.php (accessed on 6 June 2020).

46. NOAA. Tropical Depression Cristobal, Cumulative Wind History. Available online: https://www.nhc.noaa. gov/refresh/graphics_at3+shtml/113241.shtml?swath\#contents (accessed on 8 June 2020).

47. INEGI. Datos Topográficos de INEGI a Escala 1:50,000. Instituto Nacional de Estadística y Geografía. Available online: https://www.inegi.org.mx/temas/topografia/ (accessed on 1 July 2020).

48. SSA. Datos Abiertos-Bases Históricas. Available online: https://www.gob.mx/salud/documentos/datosabiertos-bases-historicas-direccion-general-de-epidemiologia (accessed on 19 July 2020).

49. Cori, A.; Ferguson, N.M.; Fraser, C.; Cauchemez, S. A new framework and software to estimate time-varying reproduction numbers during epidemics. Am. J. Epidemiol. 2013, 178, 1505-1512. [CrossRef]

50. RC Team. R: A Language and Environment for Statistical Computing; R Foundation for Statistical Computing: Vienna, Austria, 2020.

51. CONAGUA. Lluvias Asociadas a Ciclones Tropicales. Available online: https://smn.conagua.gob.mx/es/ ciclones-tropicales/lluvias-asociadas-a-ciclones-tropicales (accessed on 6 June 2020).

52. CENAPRED. Guía para la Prevención, Preparación y Gestión de las Emergencias en el Contexto del COVID-19; Centro Nacional de Prevención de Desastres (CENAPRED): Ciudad de México, Mexico, 2020. 
53. INIFAP. Perspectiva Climática para la República Mexicana (Junio-Agosto del 2020). Instituto Nacional de Investigaciones Forestales, Agrícolas y Pecuarios. Available online: http://clima.inifap.gob.mx/lnmysr (accessed on 10 July 2020).

54. GOBERNACION. Pronóstico de Lluvias del 1 al 10 de Junio del 2020. Available online: https://www.gob. mx/cms/uploads/attachment/file/555136/Pronostico_de_lluvias_a_10_dias_001_junio_2020.pdf (accessed on 21 July 2020).

55. CONAGUA. Presenta el Servicio Meteorológico Nacional Balance de las Tormentas Tropicales Amanda y Cristobal; Comisión Nacional del Agua: Ciudad de México, Mexico, 2020.

56. SEPROCI. Reporte de la Comisión de Evaluación de Daños del Meteoro Cristobal. Secretaria de Protección Civil de Campeche. Available online: http://www.seprocicam.gob.mx/index.php/comunicacion-social/1385reunion-con-el-comite-de-ayuda-de-desastres-y-emergencia-nacionales-cadena (accessed on 12 July 2020).

57. Quigley, M.C.; Attanayake, J.; King, A.; Prideaux, F. A multi-hazards earth science perspective on the COVID-19 pandemic: The potential for concurrent and cascading crises. Environ. Syst. Decis. 2019, 1, 199-215.

58. Ishiwatari, M.; Koike, T.; Hiroki, K.; Toda, T.; Katsube, T. Managing disasters amid COVID-19 pandemic: Approaches of response to flood disasters. Prog. Disaster Sci. 2020, 6, 100096. [CrossRef]

Publisher's Note: MDPI stays neutral with regard to jurisdictional claims in published maps and institutional affiliations.

(C) 2020 by the authors. Licensee MDPI, Basel, Switzerland. This article is an open access article distributed under the terms and conditions of the Creative Commons Attribution (CC BY) license (http://creativecommons.org/licenses/by/4.0/). 